\title{
Improving Students' Speaking Skill Through Role Plays: A Classroom Action Research at MTs Mualimin Muhammadiyah Yogyakarta in Academic Year 2011/2012
}

\author{
Juang Kurniawan Syahruzah \\ Fakultas Kuguruan dan Ilmu Pendidikan \\ Universitas PGRI Yogyakarta
}

\begin{abstract}
The aim of this research is to find out how the implementation of role plays can improve the students' speaking skill of grade VII of MTs Mualimin Muhammadiyah Yogyakarta in academic year 2011/2012 and how students respond to the use of role plays methods in teaching and learning process.

This research is an action research. In this study the researcher uses action research theory proposed by Kemmis and McTaggart. The participants of the research are the students of grade VII of MTs Mualimin Muhammadiyah Yogyakarta in academic year 2011/2012. The research instrument used by the writer is in the form of observation checklist and test. The data in the research are mainly gathered through the use of pre-test, observation, questionnaires, and post-test. After the data are collected, the researcher analyzes them. The researcher uses the pre-test as the basis for measuring the students' reading skill.

The finding of the research shows that the implementation of translation and discussion can improve students' speaking skill of grade VII of MTs Muhammmadiyah Yogyakarta in academic year 2011/2012. In the pre-test result, in which they formerly did not learn using discussion and translation, the mean of the pre-test was 55.64. After they learnt English using discussion and translation, the mean of the post-test was 63.3. The students' response was positive when role plays methods were applied in teaching speaking.
\end{abstract}

Keywords: Speaking, role play

\section{A. Background}

English is now the global language which is not only used in the countries of its native speakers, but also in many other countries. It is not only used by tourist guides, but also politicians, businessmen, educators, and other professionals. Ability to communicate in English is an important thing for professionals. They can develop their professionalism by communicating with more professionals from many countries using an international language as the means of communication. With English, they maintain involvement in the global era. In other words, the inability to communicate in English may lead people to fail to be involved in many fields, such as in business, education, and technology.

Language has central role in the development of intellectual, social and emotional of the learners and it is the support of the success of learning any other subjects. Language learning is 
expected to be able to help learners to know and understand themselves, their culture and other cultures. Language learning also helps learners to be able to express their ideas, feeling, to take part in society and even to use analytical and imaginative ability that they posses (Departemen Pendidikan Nasional, 2004 )

Language learning in Competence Based Curriculum (CBC) was implemented (Departemen Pendidikan Nasional, 2004) to emphasize communicative competence of the learners. Communicating here means understanding and expressing information, thought, feeling, and developing science, knowledge and culture. Learners are supposed to master communicative competence that is to master discourse competence, the ability to understand and to produce spoken and written texts which are realized in 4 language skills: listening, speaking, reading, and writing. The evaluation is done and measured with authentic assessment.

Notions about how best to teach English language learners have changed over the years and have been influenced by research in how second languages are learned. Today, the most accepted instructional frame work is communicative language teaching (CLT). The goal of CLT is to increase communicative competence, which means being able to understand and interpret messages, understand the social contexts in which language is being used, apply the rules of grammar, and employ strategies to keep communication from breaking down (Savignon, 2004)

\section{B. Methodology}

\section{Role plays}

Incorporating role-play into the classroom adds variety, a change of pace and opportunities for a lot of language production and also a lot of fun! It can be an integral part of the class and not a 'one-off' event. If the teacher believes that the activity will work and the necessary support is provided, it can be very successful. However, if the teacher isn't convinced about the validity of using role play the activity "will fall flat on its face just as you expected it to" (Gillian Porter Ladousse 1987).

Simulations and role playing exercises are one of the oldest of educational methods, having been used in ancient times and from young age. (Young children role play "doctor" and "nurse", "customers" and "shop owners" etc.) They have been used extensively in vocational training situations and in vocation-oriented higher-education courses (e.g. Law, Medicine, and Economics) since the 1960s. 


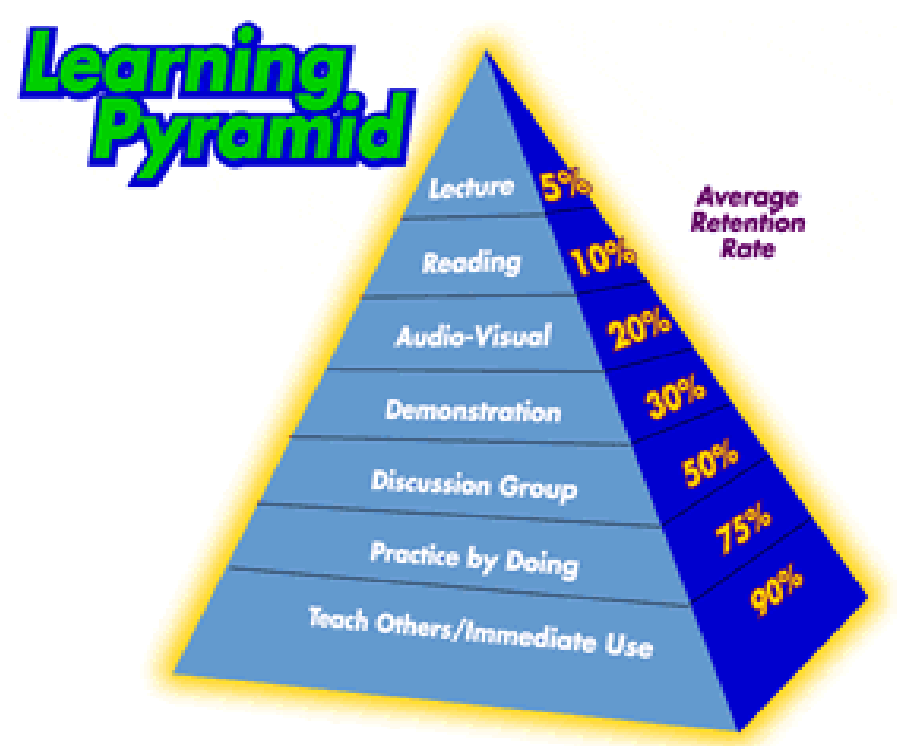

In his cone learning pyramid, Dale described that lecturing makes only $5 \%$ average retention scale, reading makes $10 \%$, audio visual makes $20 \%$, demonstration makes $30 \%$, discussion group makes $50 \%$, practice by doing makes $75 \%$ and teach others or immediate use makes $90 \%$ average retention rate. (Dale in Active learning, 2000)

Dale (1969) in his learning pyramid stated that even the use of audio-visual materials with all their production costs have only $20 \%$ memory retention. While discussions in online courses give greater learner participation than in most face-to-face courses in higher education, this teaching strategy is still only enabling 50\% memory retention and an interesting question for future research would be the effectiveness of discussion/reflection after the learners have done a practical activity in an authentic context or taught others.

\section{Speaking competence}

a. What is meant by speaking a second language?

The goal of teaching speaking skills is communicative efficiency. Learners should be able to make themselves understood, using their current proficiency to the fullest. They should try to avoid confusion in the message due to faulty pronunciation, grammar, or vocabulary, and to observe the social and cultural rules that apply in each communication situation. (The National Capital Language Resource Center, Washington, DC)

Like writing, speaking is a complex skill requiring the simultaneous use of a number of different abilities which often develop at different rates. Either four or five components are generally recognized in analysis of the speech process:

a. Pronunciation (including the segmental features-vowels and consonants-and the stress and intonation patterns)

b. Grammar

c. Vocabulary 


\section{d. Fluency (the case and speed of the flow of speech)}

To these should probably be added (5) Comprehension, for oral communication certainly requires a subject to respond to speech as well as to initiate it. When we refer to a student's skill in speaking a second language, our fundamental concern is with his ability to communicate informally on everyday subjects with sufficient ease and fluency to hold the attention of his listener. Thus in our tests of speaking ability we are primarily, if not solely, interested in the foreign student's control of the signaling systems of English-his pronunciation, grammar, and vocabulary-and not with the idea content or formal organization of the message he conveys.

\section{Introduction of research methodology}

This research is a classroom action research. A research which is done in the classroom by a teacher during the learning and teaching process. It is the qualitative research which is supported by quantitative data. This chapter will discuss the classroom action research.

"Action research is the process through which teachers collaborate in evaluating their practice jointly; raise awareness of their personal theory; articulate a shared conception of values; try out new strategies to render the values expressed in their practice more consistent with the educational values they espouse; record their work in a form which is readily available to and understandable by other teachers; and thus develop a shared theory of teaching by researching practice." - John Elliott

Action Research is a process in which participants examine their own educational practice systematically and carefully using the techniques of research. It is based on the following assumptions:

1. teachers and principals work best on problems they have identified for themselves;

2. teachers and principals become more effective when encouraged to examine and assess their own work and then consider ways of working differently;

3. teachers and principals help each other by working collaboratively;

4. Working with colleagues helps teachers and principals in their professional development.

The setting was class VII Junior High School of Madrasah Mu'allimin Muhammadiyah Yogyakarta. This site was chosen to be the site of the research because this is the class where the researcher teaches, as the characteristic of classroom action research is the teacher became the researcher in her/ his own class. Other reasons are this class is good class with motivated students, but most of the students still have low speaking competence.

Junior high school Madrasah Mu'allimin Muhammadiyah Yogyakarta is one of an oldest school, located in Wirobrajan sub district, Yogyakarta regency, DIY. It has 32 classes with 1200 students and 56 teachers and staff. 
The research was conducted in one year from July 2011 up to June 2012. The research is conducted in 3 cycles, with each cycle lasts for about 4 months. The following table shows the scenario of the cycles:

Table 4. Design of study, done in 3 cycles in academic year 2011/2012

\begin{tabular}{|c|c|c|c|}
\hline No & Cycle & Activity & Time \\
\hline 1 & Cycle I & $\begin{array}{l}\text { 1. Introduction to role play model } \\
\text { 2. Generating ideas } \\
\text { 3. Making draft for speaking } \\
\text { 4. speaking performance } \\
\text { 5. discusing the performance result } \\
\text { 6. Editing } \\
\text { 7. Reflection }\end{array}$ & $\begin{array}{l}\text { September - } \\
\text { novemver } \\
2011\end{array}$ \\
\hline 2 & Cycle II & $\begin{array}{l}\text { 1. Discussing reflection in cycle I } \\
\text { 2. Make betterment based on the reflection } \\
\text { 3. Generating ideas for speaking } \\
\text { 4. Making draft } \\
\text { 5. speaking performance } \\
\text { 6. discussing the result of performance } \\
\text { 7. revising } \\
\text { 8. Reflection }\end{array}$ & $\begin{array}{l}\text { December } \\
2011 \\
\text { february } \\
2012\end{array}$ \\
\hline 3 & Cycle III & $\begin{array}{l}\text { 1. Discussing reflection in cycle II } \\
\text { 2. Make betterment based on the reflection } \\
\text { 3. Generating ideas } \\
\text { 4. Making draft } \\
\text { 5. speaking performance } \\
\text { 6. Reflection }\end{array}$ & $\begin{array}{l}\text { March - may } \\
2012\end{array}$ \\
\hline
\end{tabular}

Tabel I. The result of the observation of students responds towards the learning using Role Play and Imaginary Conversation to enhance the speaking and writing competence. The questionnaires were given three times on November 2 2011, February 152012 and May 52012

\begin{tabular}{|c|c|c|c|c|c|c|c|c|}
\hline \multirow[t]{2}{*}{ No } & \multirow[t]{2}{*}{ Statement } & \multirow[t]{2}{*}{ Respond } & \multicolumn{2}{|c|}{ Cycle I } & \multicolumn{2}{|c|}{ Cycle II } & \multicolumn{2}{|c|}{ Cycle III } \\
\hline & & & Total & $\%$ & Total & $\%$ & Tot & $\%$ \\
\hline \multirow[t]{3}{*}{1} & \multirow[t]{3}{*}{ I like learning English } & agree & 10 & 30,30 & 19 & 57,57 & 26 & 78,78 \\
\hline & & Not sure & 9 & 27,27 & 6 & 18,18 & 2 & 6,6 \\
\hline & & disagree & 14 & 42,42 & 8 & 24,24 & 3 & 9,9 \\
\hline
\end{tabular}


ISSN : 2407-0742

\begin{tabular}{|c|c|c|c|c|c|c|c|c|}
\hline \multirow[t]{3}{*}{2} & \multirow{3}{*}{$\begin{array}{l}\text { I can express my ideas well } \\
\text { in speaking }\end{array}$} & agree & 4 & 12,12 & 14 & 36,36 & 24 & 72,72 \\
\hline & & Not sure & 13 & 39,39 & 10 & 30,30 & 7 & 21,21 \\
\hline & & disagree & 16 & 48,48 & 9 & 27,27 & 2 & 6,6 \\
\hline \multirow[t]{3}{*}{3} & \multirow[t]{3}{*}{ I use English often } & agree & 6 & 18,18 & 17 & 51,51 & 23 & 69,69 \\
\hline & & Not sure & 13 & 39,39 & 8 & 24,24 & 9 & 27,27 \\
\hline & & disagree & 14 & 52,52 & 8 & 24,24 & 4 & 12,12 \\
\hline \multirow[t]{3}{*}{4} & \multirow{3}{*}{$\begin{array}{l}\text { I can organize ideas well in } \\
\text { speaking }\end{array}$} & agree & 9 & 27,27 & 17 & 51,51 & 23 & 69,69 \\
\hline & & Not sure & 8 & 24,24 & 6 & 18,18 & 5 & 15,15 \\
\hline & & disagree & 16 & 48,48 & 10 & 30,30 & 5 & 15,15 \\
\hline \multirow[t]{3}{*}{5} & \multirow{3}{*}{$\begin{array}{l}\text { Role play helps me a lot in } \\
\text { organizing ideas }\end{array}$} & agree & 11 & 33,33 & 15 & 45,45 & 26 & 72,72 \\
\hline & & Not sure & 12 & 36,36 & 7 & 21,21 & 3 & 9,9 \\
\hline & & disagree & 10 & 30,30 & 6 & 18,18 & 4 & 12,12 \\
\hline \multirow[t]{3}{*}{6} & \multirow{3}{*}{$\begin{array}{l}\text { Role play helps me explore } \\
\text { more ideas on certain topics }\end{array}$} & agree & 13 & 39,39 & 19 & 57,57 & 24 & 72,72 \\
\hline & & Not sure & 11 & 33,33 & 8 & 24,24 & 5 & 15,15 \\
\hline & & disagree & 9 & 27,27 & 6 & 18,18 & 4 & 12,12 \\
\hline \multirow[t]{3}{*}{7} & \multirow{3}{*}{$\begin{array}{l}\text { I like to learn collaboratively } \\
\text { and cooperatively with } \\
\text { friends }\end{array}$} & agree & 14 & 42,42 & 18 & 48,48 & 26 & 78,78 \\
\hline & & Not sure & 8 & 24,24 & 7 & 21,21 & 4 & 12,12 \\
\hline & & disagree & 11 & 33,33 & 8 & 24,24 & 3 & 9,9 \\
\hline \multirow[t]{3}{*}{8} & \multirow[t]{3}{*}{ I like to try to speak English } & agree & 12 & 36,36 & 20 & 60,60 & 25 & 75,75 \\
\hline & & Not sure & 8 & 24,24 & 5 & 15,15 & 4 & 12,12 \\
\hline & & disagree & 13 & 39,39 & 8 & 24,24 & 4 & 12,12 \\
\hline \multirow[t]{3}{*}{9} & \multirow{3}{*}{$\begin{array}{l}\text { I like to tell a story in } \\
\text { English }\end{array}$} & agree & 10 & 30,30 & 17 & 51,51 & 22 & 66,66 \\
\hline & & Not sure & 9 & 27,27 & 8 & 24,24 & 6 & 18,18 \\
\hline & & disagree & 14 & 42,42 & 8 & 24,24 & 5 & 15,15 \\
\hline \multirow[t]{3}{*}{10} & \multirow[t]{3}{*}{ I can speak English well } & agree & 12 & 36,36 & 17 & 51,51 & 25 & 75,75 \\
\hline & & Not sure & 13 & 39,39 & 9 & 27,27 & 5 & 15,15 \\
\hline & & disagree & 8 & 24,24 & 5 & 15,15 & 3 & 9,9 \\
\hline
\end{tabular}

\section{Discussion}

Based on the classroom action research in learning and teaching process, the application of role play and imaginary conversation to enhance students speaking and writing competence, it is concluded that :

1. Role play gives positive contribution to enhance students speaking competence. Students get significant increase in speaking score which indicates the increase in speaking competence 
2. Role plays significantly improve student's ability to generate and organize ideas. Being given provoking stimulus like situation, condition, pictures, film, music and other things, students can generate ideas easily.

3. Role plays make students explore a topic from different perspective. Role play make students place themselves in others' mind, thought and feeling and make them see and think something from different point of view.

4. Role play increase students self confident in speaking for they prepare themselves better and they are ready. Being exposed to the topic, helped with vocabularies and target linguistic features which might be used, students have good preparation and readiness.

5. Role plays increase students' creativity to use the language. Different role the students play provide students with different kind of situation and communication they may create.

6. Role plays make students love learning. To play the role play games, students need background knowledge according to the role they play. Students prepare themselves with the knowledge about the role they write.

Role plays increase students' critical thinking. Role play and Imaginary conversation demand student respond quickly. The situation, the play made in the activities make students express their ideas, thought and feeling. Students train to think critically forced and stimulated by the activities.

\section{Reference}

Kurikulum 2004, Standar Kompetensi Mata Pelajaran Bahasa Inggris Sekolah Menengah Atas dan madrasah Aliyah .Departemen Pendidikan Nasional Jakarta 2004.

Savignon, S. (1997). Communicative Competence: Theory and Classroom Practice. New York: McGraw-Hill

Canale, M. and Swain, M. (1980). Theoretical bases of communicative approaches to second language teaching and testing. Applied Linguistics 1, 1-47.

Bachman, L. (1990). Fundamental considerations in language testing. Oxford: Oxford University Press. ISBN 0-19-437003-8

Celce Murcia in Kurikulum 2004, Standar Kompetensi Mata Pelajaran Bahasa Inggris Sekolah Menengah Atas dan madrasah Aliyah .Departemen Pendidikan Nasional Jakarta 2004.

Gillian in Rilstone, Andrew. 1994 "Role-Playing Games: An Overview", Inter*Action \#1 at http://www.rpg.net/oracle/essays/rpgoverview.html

Rilstone Andrew, 1994 "Role-Playing Games: An Overview" Inter*Action \#1 at http://www.rpg.net/oracle/essays/rpgoverview.html 
Ayckbourn in Rilstone, Andrew. 1994 "Role-Playing Games: An Overview", Inter*Action \#1 at http://www.rpg.net/oracle/essays/rpgoverview.html

Gredler, M. (1992), Designing and Evaluating Games and Simulations: A Process Approach, Kogan Page, London 